\title{
Cell fusion and plasticity
}

\author{
Joseph J. Lucas ${ }^{1} \&$ Naohiro Terada ${ }^{2 *}$ \\ ${ }^{1}$ Department of Pediatrics, National Jewish Medical and Research Center, Denver, CO, U.S.A.; ${ }^{2}$ Department of \\ Pathology, University of Florida College of Medicine, Gainesville, FL, U.S.A. \\ (*Author for correspondence; E-mail: terada@pathology.ufl.edu; Fax: +1 (352) 392 6249)
}

Key words: cell fusion, cloning, plasticity, stem cell, transdifferentiation

\begin{abstract}
Cell plasticity is a central issue in stem cell biology. In many recent discussions, observation of cell fusion has been seen as a confounding factor which calls into question published results concerning cell plasticity of, particularly, adult stem cells. An examination of the voluminous literature of "somatic cell fusion" suggests the relatively frequent occurrence of "spontaneous" cell fusion and shows that the complicated cellular phenotypes which it can give rise to have long been recognized. Here, a brief overview of this field is presented, with emphasis on studies of special relevance to current work on cell plasticity.
\end{abstract}

\section{Introduction}

Cell plasticity is a central issue in stem cell biology. Mammalian cloning has proven to be a reproducible technique in multiple species, clearly indicating that mammalian somatic nuclei, even from fully differentiated cells, can be reprogrammed into a totipotent status when placed in enucleated oocytes (Wilmut et al., 2002). Moreover, recent publications claim that somatic stem cells can convert into developmentallyunrelated cell types both in vivo and ex vivo without the manipulations of nuclear transfer (Eglitis and Mezey, 1997; Ferrari et al., 1998; Gussoni et al., 1999; Petersen et al., 1999; Brazelton et al., 2000; Lagasse et al., 2000; Mezey et al., 2000; Theise et al., 2000; Jackson et al., 2001; Krause et al., 2001; Orlic et al., 2001; Shimizu et al., 2001; Jiang et al., 2002; Korbling et al., 2002; Sata et al., 2002). These exciting possibilities of 'transdifferentiation' have become of great interest in recent stem cell research for multiple reasons. First, they call into question traditional concepts of cell lineage and development. Second, they raise the possibility that relatively accessible stem cells, for example hematopoietic stem cells, could be used to repair organs from which stem cells are not easily isolated, such as the brain. Finally, the possib- ility of directed differentiation or transdifferentiation of adult stem cells raises the possibility that the use of human embryonic stem (ES) cells, which raises contentious ethical and political issues, could be avoided. Despite recommendations of caution by several experienced investigators (see for example, Weissman et al. (2001) and Lemischka (2002)), these reports have inspired speculation that adult stem cells could become nearly any cell type simply by incubation in a suitable culture environment or by transplantation into appropriate sites in the body. However, two research papers (Terada et al., 2002; Ying et al., 2002) now cast doubt on many claims of transdifferentiation by proposing an alternative hypothesis. In these reports, either bone marrow cells or brain cells, genetically marked with green fluorescent protein (GFP), spontaneously fused to ES cells in mixed cultures, resulting in GFP-positive hybrid cells having the pluripotent trait of ES cells. Indeed, generation of the GFP-positive pluripotent cells could have been misinterpreted as dedifferentiation of somatic cells, as described in many recent 'transdifferentiation' reports, if detailed genetic analysis had not been performed. With these new reports, it was realized that many previous studies had failed to provide adequate genetic or other convincing evidence of cell identity to sub- 
stantiate claims of transdifferentiation. Some recent discussions suggest that spontaneous fusion and the characteristics of the resultant cells are perhaps more surprising than 'transdifferentiation' (see for example, McKay (2002) and Tsai et al. (2002)). In fact, an examination of the voluminous literature of 'somatic cell fusion' suggests otherwise - the relatively frequent occurrence of 'spontaneous' cell fusion and the complicated cellular phenotypes which it can give rise to have long been recognized. Here, a brief overview of this field is presented, with emphasis on studies of special relevance to current work on cell plasticity.

\section{'Spontaneous' cell fusion}

Cell fusion is a natural occurrence in multicellular organisms. Some notable examples in animals are fusion of egg and sperm during fertilazation, the formation of multinucleated myotubes by fusion of myoblasts and the generation of osteoclasts by fusion of mononuclear phagocytic precursor cells. Cell fusion may also be observed under pathological conditions induced by cell injury, certain viral or bacterial infections and during malignant cell growth (Ringertz and Savage, 1976; Hernandez et al., 1996). Understanding of the molecular mechanisms involved in plasma cell membrane fusion has advanced dramatically in recent years, as discussed elsewhere (Vignery, 2000; White and Rose, 2001; Taylor, 2002).

As observed by the earliest developers of cell culture techniques, cell fusion also occurs when animal cells are placed in vitro, even between cell types not normally observed to fuse in the intact animal. Such events may be induced by the artificial conditions of the in vitro environment; however, that they may be, at least in some cases, also reflective of natural events in the animal can not be excluded.

As described in Ringertz and Savage's classic review (1976) of the literature of cell fusion, W. H. Lewis (1927) described the occurrence of 'spontaneous' cell fusion as a mechanism for generating multinucleated cells from both tumor and normal tissue cells placed in vitro. The formation of hybrid cell lines resulting from such spontaneous fusion events was not proven until more than thirty years later, when Barski and colleagues $(1961,1962)$ isolated such cells from mixed cultures of two different sarcoma-forming mouse cell lines and showed that they possessed the karyotype and other marker properties expected of synkaryons (cells having chromosomes derived from both parents in a single nucleus). Cell fusion was soon confirmed using a variety of different cell types. It is noteworthy that the first use of a genetic selection technique for isolating hybrid cells, Littlefield's (1964) refinement and application of the 'HAT' (hypoxanthineaminopterin-thymidine) selection method of Szybalski et al. (1962), was used to isolate hybrid cells formed 'spontaneously' in mixed cultures of A9(HGPRT' ${ }^{-}$) and $\mathrm{B} 82\left(\mathrm{TK}^{-}\right)$mouse cells. Davidson and Ephrussi (1965) soon adapted this method to isolate hybrids formed spontaneously in mixed cultures of A9 cells and normal mouse cells. A9 parental cells died in the HAT medium. Normal mouse cells formed a monolayer of cells and soon stopped growing. Hybrids could survive in the HAT medium; in addition they had acquired from the A9 parent the property of vigorous growth in culture and had lost the property of "contact inhibition' of growth exhibited by the normal cells.

These early studies illustrate some important concepts of relevance to recent reports of spontaneous cell fusion in culture. First is the observation that hybrid cells, though burdened with a double complement of chromosomes, may, because of the combination of traits they acquire, sometimes grow more rapidly than one or even both parental cell types. In fact, the term 'hybrid vigor', borrowed from the jargon of plant and animal breeders, has been used to describe this trait (see Ringertz and Savage, 1976). Those experienced in tissue culture applications will appreciate that cells with even a slight growth advantage can, in a reasonably short amount of time, become a major component of a mixed cell culture. Secondly, the studies demonstrate that cell fusion is a relatively common event in mixed cell cultures, occurring with cells of many species and phenotypes. The comprehensive review of these early studies by Ringertz and Savage (1976) led to the conclusion that 'spontaneous' fusion of cells in culture occurs with a frequency between one in one hundred and one in one million cells, depending on cell type and culture conditions. These authors also pointed out that 'spontaneous' events in biology are 'those for which a cause is not known', an important observation still relevant today.

\section{Cell fusion and plasticity}

Development of methods for inducing cell fusion at higher frequencies, first using viruses, most notably Sendai virus (Okada, 1958; Harris and Watkins, 1965; Okada and Murayama, 1965) and then chemicals such 
as polyethylene glycol (Pontecorvo, 1976), led to the use of cell hybrids in a variety of studies. An early application of the method was the mapping of genes to chromosomes (Ruddle et al., 1971; Ruddle and Kucherlapati, 1974). Weiss and Green (1967) formed hybrids from human and mouse cells and demonstrated that the synkaryons tended to lose human chromosomes upon prolonged growth. Extensive studies of cell hybrids formed from cells derived from a variety of organisms led to the observation that in such cross-species hybrids, the chromosomes of one species were preferentially lost - human chromosomes are generally discarded in mouse/human cell hybrids (Weiss and Green, 1967; Migeon and Miller, 1968) but retained in human/mosquito cell hybrids (Zepp et al., 1971). Perhaps of most relevance to recent studies, however, is the fact that intraspecific hybrids, especially those formed from normal cells rather than cell lines, show a much greater chromosomal stability than interspecies hybrids (Engel et al., 1969; Bengtsson et al., 1975). In summary, cell hybrids formed in culture or in vivo, though relatively rare and having a high chromosome number, may persist and even grow vigorously while expressing a mixed set of traits. As described below, the set of phenotypic traits expressed by such hybrid cells is hard to predict, though the literature of the era of 'somatic cell fusion' does lead to some generalizations.

Many early cell fusion experiments were directed toward gaining insight into the mechanisms of cell differentiation and gene expression - could the program of genes expressed by a differentiated cell be fundamentally altered? No doubt many of these studies were inspired by dramatic advances in the field of nuclear transplantation using cells derived from lower eukaryotic organisms, most notably those reported by Gurdon and collaborators with Xenopus laevis (Fischberg et al., 1958; Gurdon, 1962; Gurdon and Melton, 1981). In brief, these remarkable studies demonstrated that animals could be formed by transplanting the nucleus of a differentiated cell into an enucleated egg. Although adult cell nuclei generally were capable of inducing only partial development, it was shown that the nuclei from larval intestinal epithelial cells were capable of producing fertile adult animals. These early studies, and others performed with Rana pipiens (Briggs and King, 1952, 1960), clearly indicated that the nuclei of at least some differentiated cells retained the competence to direct the formation of an entire animal, that is, were genetically totipotent. Since these early studies, the techniques of somatic cell nuclear transfer have been adapted to a wide variety of mammalian species, including sheep, cattle, mice, pigs, goats rabbits and cats (reviewed by Wilmut et al., 2002).

The technique of induced somatic cell fusion in vitro permitted analysis of fundamental questions of developmental biology in higher animals. In the earliest studies, cells expressing traits characteristic of two differentiated states were fused and the progeny synkaryon cell lines were then analyzed for the traits. In some studies, individual heterokaryons (cells containing two different types of nuclei in a mixed cytoplasm) were analyzed. With development of the technique of cytochalasin-induced cell enucleation (Carter, 1967; Prescott et al., 1972; Wright and Hayflick, 1972), some refinements of the basic protocol became possible. In 'cybridization' experiments, a cytoplast (a cell's cytoplasmic component surrounded by a plasma membrane) was fused to a whole cell of another type (Poste and Reeve 1971, 1972; Bunn et al., 1974). In 'cell reconstruction' (Veomett et al., 1974) or 'nuclear transplantation' (Lucas and Kates, 1976), a cytoplast from one cell type was fused to a karyoplast (a nucleus surrounded by a thin shell of cytoplasm and a plasma membrane) of another cell type. Cell hybrids, cybrids and reconstituted cells were all used to address the basic concept of cell plasticity - could a cell be reprogrammed to express genes characteristic of another differentiated state?

The earliest studies of differentiated traits in hybrid cells entailed the study of pigmentation (melanin synthesis) in cells formed from hamster melanoma and mouse fibroblast cells (Davidson et al., 1966, 1968). In these studies, pigmentation was lost or 'extinguished' in hybrid cells. Shortly after these reports, Weiss and collaborators began an extensive study of hybrids formed between rat hepatoma and mouse nonliver cells (see for example, Schneider and Weiss (1971), Fougere and Weiss (1978), and Mevel-Ninio and Weiss (1981)). Although they too initially saw extinction of traits associated with the hepatic phenotype, further analysis revealed that, upon loss of mouse chromosomes, rat liver traits could be re-expressed. Furthermore, some of the hybrid cell lines went on to express mouse liver-specific products. These phenomena of gene 'extinction', 're-expression', and 'crossactivation' were subsequently seen in a wide variety of cell fusion studies, as described in the reviews cited above and elsewhere (Lucas, 1983; Blau and Blakely, 1999). In general, techniques of cybridization and cell reconstruction substantiated the results of whole cell 
fusion, except that the phenomena observed were generally transient in nature. For example, fusion of a mouse fibroblast cytoplast to a rat hepatoma cell 'extinguished' albumin synthesis, but for no more than $48 \mathrm{hr}$ (Kahn et al., 1981a). Transient activation of liver-specific functions by non-liver nuclei after exposure to hepatoma cytoplasm was also described, but this phenomenon may have been due at least in part to selective pressure exerted in the cell culture system used (Gopalakrishnan and Anderson, 1979; Kahn et al., 1981b).

In their discussion 'Cell Commitment and Differentiation', Maclean and Hall (1987) singled out three experimental systems from the literature of somatic cell fusion which may be most pertinent to the topic of nuclear re-programming and cell plasticity. In the first, mouse teratoma cells were fused to Friend erythroleukemia cells, and globin genes in the teratoma nuclei were induced (McBurney et al., 1978). In the second, mouse fibroblast nuclei were placed into cytoplasts from rat hepatoma cells and transient expression of the liver-specific mouse tyrosine aminotransferase was observed (Lipsich et al., 1979). In the third system, Blau and collaborators $(1983,1985)$ produced heterokaryons from mouse muscle cells and a variety of human cell types. The cells survived for many days as non-dividing multi-nucleated heterokaryons. The synthesis of several human muscle specific proteins was definitively demonstrated. The use of 'transient heterokaryons' was subsequently used to show the partial reprogramming of cells to other differentiated states, including erythroid (Baron and Maniatis, 1986), hepatic (Spear and Tilghman, 1990) and pancreatic (Wu et al., 1991) lineages. A partial reprogramming of erythroid cell nuclei was also seen when they were transplanted into enucleated cells (Bruno et al., 1981). Although not as comprehensive as the results of the amphibian nuclear transplantation studies, these results nonetheless argued for a remarkable degree of genome plasticity in adult somatic cells.

Of special interest here were other cell fusion studies which used as one fusion partner teratocarcinoma cells, embryonic stem (ES) cells or embryonic germ (EG) cells. Initial studies appeared to indicate that fusion to a transformed somatic cell line suppressed the differentiation capacity of teratoma cells (Finch and Ephrussi, 1967; Jami et al., 1973). The apparent suppression of pluripotency in cell hybrids was substantiated by McBurney and Strut (1979) using embryonal carcinoma cells and mouse 3T3 fibroblasts; in contrast, retention of pluripotency was reported in fusions between embryonal carcinoma cells and thymocytes (Miller and Ruddle, 1976) and also in hybrids with erythroleukemia cells, if the embryonic carcinoma cells used were a tetraploid line, indicating a 'gene dosage' effect (McBurney, 1977). Iwakura and colleagues (1985) suggested that mouse embryonal carcinoma cells could by induced to differentiate into various morphological types by fusion to enucleated rat myoblasts and argued for the presence of cytoplasmic regulators of gene expression which could direct expression in the embryonal carcinoma cell nuclei. As noted above, McBurney and colleagues (1978) had shown that teratoma cell nuclei could apparently be induced to express globin genes after fusion to erythroleukemia cells. Also, reactivation of the inactive $\mathrm{X}$ chromosome was demonstrated when thymocytes were fused with embryonal carcinoma cells (Takagi et al., 1983). Later experiments with normal stem and germ cells clearly suggested dominance of the pluripotent cell genome, at least with respect to the properties studied (reviewed by Surani, 2001) For example, Tada et al. (2001) have shown reactivation of the Oct-4 gene, which is normally expressed only in totipotent and pluripotent cells (Yeom et al., 1996; Pesce et al., 1998), in the somatic nucleus of hybrids between stem cells and thymocytes. Embryonic germ cells cause similar changes in somatic cell nuclei and, in addition, induce alterations in the status of imprinted alleles (Tada et al., 1997). Furthermore, both types of hybrid cells, those of somatic cells with ES or EG cells, retain their pluripotent capacity when placed into blastocysts (Tada et al., 1997, 2001).

Taken together, the results of somatic cell fusion experiments indicate the existence of transferable factors which can suppress or induce gene expression. Similar studies focused on cell cycle progression rather than gene expression likewise suggest the existence of factors which could induce premature entry into phases of the cell cycle (Rao and Johnson, 1970). In a dramatic example of this latter phenomenon, Lipsich et al. (1978) showed that dormant, terminally differentiated nuclei from chicken erythrocytes could be reactivated when placed in enucleated mouse cytoplasts; however when placed in cytoplasts isolated from cells synchronized in the S-phase of the cell cycle, the reactivating nuclei also began synthesizing DNA. Mercer and Schlegel (1982) showed that fusion with cytoplasts prepared from S-phase cells could also induce quiescent fibroblasts to re-enter the cell cycle and begin DNA replication. These results are of interest here since it is clear that many specialized, i.e., 
fully differentiated cells in the body are withdrawn from the cell cycle, and clearly need to be returned to a proliferative state if they are to support development of an embryo or if they are to serve as the source of cell cultures for therapeutic applications.

Molecular analyses of gene expression and cell cycle progression now lend plausible explanations for many of the phenomenon seen in cell fusion experiments. For example, expression of cell cycle stimulatory proteins such as cyclin E can prematurely induce cells to enter S-phase (Resnitzky et al., 1994; Wimmel et al., 1994). Similarly, with respect to inducible gene expression, individual transcription factors which can have dramatic effects on the program of genes expressed have been identified; for example, ectopic expression of members of the MRF (muscle regulatory factors) family of transcription factors can induce activation of muscle-specific genes in non-muscle cell types (Davis et al., 1987; Choi et al., 1990; Russo et al., 1998). In retrospect, it seems obvious that such potent trans-acting factors were transferred from one cell type to another by the techniques of somatic cell fusion.

\section{Concluding remarks}

In summary, early results obtained by nuclear transplantation with amphibians combined with somatic cell fusion experiments provided evidence for the potential pluripotency of somatic cell nuclei and for their capacity to be re-programmed. As such, they provided a background of both information and inspiration for subsequent work which resulted in dramatic successes in mammalian cloning (reviewed by Wilmut et al., 2002). Recent observations on the spontaneous fusion of somatic cells and ES cells resulting in pluripotent hybrid cells (Ying et al., 2002; Terada et al., 2002) indicates that these early studies may now be of more than historical interest. In the discussion above, several traits of hybrid cells which may have relevance to current studies were emphasized.

In many recent discussions, observation of cell fusion has been seen as a confounding factor which calls into question published results concerning stem cell activities. These observations may be seen in another light as an opportunity for developing new methods and approaches for intractable clinical problems. For example, could cell fusion in vivo be used as a means to deliver genes to cells which are damaged or to organs in need of cell replenishment? Could cells ex- pressing a particular phenotype be constructed in vitro by cell fusion and then be targeted to a particular site in the body? It is predicted that further studies on cell fusion and genome plasticity, designed with knowledge of the extremely large and diverse literature touched upon only briefly here, should lead to new and important insights and eventual therapies.

\section{References}

Baron MH \& Maniatis T (1986) Rapid reprogramming of globin gene expression in transient heterokaryons. Cell 46: 591-562.

Barski G, Sorieul S \& Cornefert F (1961) 'Hybrid' type cells in combined cultures of two different mammalian cell strains. J Natl Cancer Inst 26: 1269-1291.

Barski G \& Cornefert F (1962) Characteristics of 'hybrid'-type clonal cell lines obtained from mixed cultures in vitro. J Natl Cancer Inst 28: 801-821.

Bengtsson BO, Nabholz M, Kennett R, Bodmer WF, Povey S \& Swallow D (1975) Human intraspecific somatic cell hybrids: A genetic and karyotypic analysis of crosses between lymphocytes and D98/AH-2. Somatic Cell Genet 1: 41-64.

Blau HM \& Blakely BT (1999) Plasticity of cell fate: Insights from heterokaryons. Cell Develop Biol 10: 267-272.

Blau HM, Chiu CP \& Webster C (1983) Cytoplasmic activation of human nuclear genes in stable heterokaryons. Cell 32: 1171-1180.

Blau HM, Parlath GK, Hardeman EC, Chin CP, Silberstein L, Webster SG, Miller SC \& Webster C (1985) Plasticity of the differentiated state. Science 230: 758-766.

Brazelton TR, Rossi FMV, Keshet GI \& Blau HM (2000) From marrow to brain: Expression of neuronal phenotypes in adult mice. Science 290: 1775-1779.

Briggs R \& King TJ (1952) Transplantation of living nuclei from blastula cells into enucleated frog's eggs. Proc Natl Acad Sci USA 38: 455-457.

Briggs R \& King TJ (1960) Nuclear transplantation studies on the early gastrula (Rana pipiens). Devel Biol 2: 252-270.

Bruno J, Reich NR \& Lucas JJ (1981) Globin synthesis in hybrid cells constructed by transplantation of dormant avian erythrocyte nuclei into enucleated fibroblasts. Mol Cell Biol 1: 1163-1176.

Bunn CL, Wallace DC and Eisenstadt JM (1974) Cytoplasmic inheritance of chloramphenicol resistance in mouse tissue cells. Proc Natl Acad Sci USA 71: 1681-1685.

Carter SB (1967) Effects of cytochalasen on mammalian cells. Nature 213: 261-266

Choi J, Costa ML, Mermelstein CS, Chagas C, Holtzer S \& Holtzer H (1990) MyoD converts primary dermal fibroblasts, chondroblasts, smooth muscle, and retinal pigmented epithelial cells into striated mononucleated myoblsts and multinucleated myotubes. Proc Natl Acad Sci USA 87: 7988-7992.

Davidson RL \& Ephrussi B (1965) A selective system for the isolation of hybrids between L cells and normal cells. Nature 205: 1170-1171.

Davidson RL, Ephrussi B \& Yamamoto K (1966) Regulation of pigment synthesis in mammalian cells as studied by somatic hybridization. Proc Natl Acad Sci USA 56: 1437-1440.

Davidson RL, Ephrussi B \& Yamamoto K (1968) Regulation of melanin synthesis in mammalian cells, as studied by somatic hybridization. I. Evidence for negative control. J Cell Physiol 72: 115-127. 
Davis RL, Weintraub H \& Lassar AB (1987) Expression of a single transfected cDNA converts fibroblasts to myoblasts. Cell 51: 987-1000.

Eglitis MA \& Mezey E (1997) Hematopoietic cells differentiate into both microglia and macroglia in the brains of adult mice. Proc Natl Acad Sci USA 94: 4080-4085.

Engel E, McGee BJ \& Harris H (1969) Cytogenettic and nuclear studies on A9 and B82 cells fused together by Sendai virus: The early phase. J Cell Sci 5: 93-120.

Ferrari G, Cusella-DeAngelis G, Coletta M, Paolucci E, Stornaiuolo A, Cossu G \& Mavilio F (1998) Muscle regeneration by bone marrow-derived myogenic progenitors. Science 279: 1528-1530.

Finch BW \& Ephrussi B (1967) Retention of multiple developmental potentialities by cells of a mouse testicular teratocarcinoma during prolonged culture in vitro and their extinction upon hybridization with cells of permanent lines. Proc Natl Acad Sci USA 57: 615-621.

Fischberg M, Gurdon JB \& Elsdale TR (1958) Nuclear transplantation in Xenopus laevis. Nature 181: 424.

Fougere C \& Weiss MC (1978) Phenotypic exclusion in mouse melanoma-rat hepatoma cells: Pigment and albumin production are not reexpressed simultaneously. Cell 15: 843-854.

Gopalakrisnan TV \& Anderson WF (1979) Epigenetic activtion of phenylalanine hydroxylase in mouse erythroleukemia cells by the cytoplast of rat hepatoma cells. Proc Natl Acad Sci USA 76: 3932-3936.

Gurdon JB (1962) Adult frogs derived from the nuclei of single somatic cells. Develop Biol 4: 256-273.

Gurdon JB \& Melton DA (1981) Gene transfer in amphibian eggs and oocytes. Ann Rev Genet 15: 189-218.

Gussoni E, Soneoka Y, Strickland CD, Buzney EA, Khan MK, Flint AF, Kunkel LM \& Mulligan RC (1999) Dystrophin expression in the mdx mouse restored by stem cell transplantation. Nature 401: 390-394.

Harris H \& Watkins JF (1965) Hybrid cells derived from mouse and man: Artificial heterokaryons of mammalian cells from different species. Nature 205: 640-646.

Hernandez LD, Hoffman LR \& White JM (1996) Virus-cell and cell-cell fusion. Annu Rev Cell Dev Biol 12: 627-661.

Iwakura Y, Nozaki M, Asano M, Yoshida MC, Tsukada Y, Hibi N, Ochiai A, Tahara E, Tosu M \& Sekiguchi T (1985) Pleiotropic phenotypic expression in cybrids derived from mouse teratocarcinoma cells fused with rat myoblasts. Cell 43: 771-779.

Jackson KA, Majka SM, Wang H, Pocius J, Hartley CJ, Majesky MW, Entman ML, Michael LH, Hirschi KK \& Goodell MA (2001) Regeneration of ischemic cardiac muscle and vascular endothelium by adult stem cells. J Clin Invest 107: 1395-1402.

Jami J, Failly C \& Ritz E (1973) Lack of expression of differentiation in mouse teratoma-fibroblast somatic cell hybrids. Exp Cell Res 76: 191-199.

Jiang Y, Jahagirdar BN, Reinhardt RL, Schwartz RE, Keene CD, Ortiz-Gonzalez XR, Reyes M, Lenvik T, Lund T, Blackstad M, Du J, Aldrich S, Lisberg A, Low WC, Largaespada DA, \& Verfaillie CM (2002) Pluripotency of mesenchymal stem cells derived from adult marrow. Nature 418: 41-9.

Kahn CR, Berttolotti R, Ninio M \& Weiss MC (1981a) Short-lived cytoplasmic regulators of gene expression in cell hybrids. Nature 290: 717-720.

Kahn CR, Gopalakrishnan TV \& Weiss MC (1981b) Transfer of heritable properties by cell cybridization: Specificity and the role of selective pressure. Somatic Cell Genet 7: 547-565.

Korbling M, Katz RL, Khanna A, Ruifrok AC, Rondon G, Albitar M, Champlin RE \& Estrov Z (2002) Hepatocytes and epithelial cells of donor origin in recipients of peripheral-blood stem cells. N Engl J Med 346: 738-746.

Krause DS, Theise ND, Collector MI, Henegariu O, Hwang S, Gardner R, Neutzel S \& Sharkis SJ (2001) Multi-organ, multi-lineage engraftment by a single bone marrow-derived stem cell. Cell 105: 369-377.

Lagasse E, Connors H, Al-Dhalimy M, Reitsma M, Dohse M, Osborne L, Wang X, Finegold M, Weissman IL \& Grompe M (2000) Purified hematopoietic stem cells can differentiate into hepatocytes in vivo. Nature Med 6: 1229-1234.

Lemiscka I (2002) Rethinking somatic stem cell plasticity (Commentary). Nature Biotechnol 20: 425.

Lewis WH (1927) The formation of giant cells in tissue culture and their similarity to those in tuberculous lesions. Am Rev Tuberc 15: 616-628.

Lipsich LA, Kates JR \& Lucas JJ (1979) Expression of a liverspecific function by mouse fibroblast nuclei transplanted into rat hepatoma cytoplasts. Nature 281: 74-76.

Lipsich LA, Lucas JJ \& Kates JR (1978) Cell cycle dependence of the reactivation of chick erythrocyte nuclei after transplantation into mouse L929 cytoplasts. J Cell Physiol 97: 199-208.

Littlefield JW (1964) Selection of hybrids from matings of fibroblasts in vitro and their presumed recombinants. Science 145: 709-710.

Lucas JJ (1983) Somatic cell hybridization. In: N Maclean, SP Gregory \& RA Flavell (eds.) Eukaryotic Genes: Their Structure, Activity and Regulation (pp. 117-126) Butterworths, London.

Lucas JJ \& Kates JR (1976) The construction of viable nuclearcytoplasmic hybrid cells by nuclear transplantation. Cell 7: 397-405.

Maclean N \& Hall BK (1987) Cell Commitment and Differentiation. Cambridge University Press, Cambridge.

McBurney MW (1977) Hemoglobin synthesis in cell hybrids formed between teratocarcinoma cells and friend erythroleukemia cells. Cell 12: 653-662.

McBurney MW, Featherstone MS \& Kaplan H (1978) Activation of teratocarcinoma-derived hemoglobin genes in teratocarcinomafriend cell hybrids. Cell 15: 1323-1330.

McBurney MW \& Strutt B (1979) Fusion of embryonal carcinoma cells to fibroblast cells, cytoplasts, and karyoplasts. Exp Cell Res 124: 171-180.

McKay R (2002) A more astonishing hypothesis (Commentary). Nature Biotechnol 20: 426-427.

Mercer WE \& Schlegel RA (1982) Cytoplasts can transfer factor(s) that stimulate quiescent fibroblasts to enter $\mathrm{S}$ phase. J Cell Physiol 110: 311-314.

Mevel-Ninio M \& Weiss MC (1981) Immunofluorescence analysis of the time-course of extinction, reexpression, and activation of albumin production in rat hepatoma-mouse fibroblast heterokaryons and hybrids. J Cell Biol 90: 339-350.

Mezey E, Chandross KJ, Harta G, Maki RA \& McKercher SR (2000) Turning blood into brain cells bearing neuronal antigens generated in vivo from bone marrow. Science 290: 1779-1782.

Migeon BR \& Miller CS (1968) Human-mouse somatic cell hybrids with single human chromosome (group E): Link with thymidine kinase activity. Science 162: 1005-1006.

Miller RA \& Ruddle FH (1976) Pluripotent teratocarcinomathymocyte somatic cell hybrids. Cell 9: 45-55.

Okada Y (1958) The fusion of Ehrlich's tumor cells caused by HVJ virus in vitro. Biken's J 1: 103-110.

Okada Y \& Murayama F (1965) Multinucleated giant cell formation by fusion between cells of two different strains. Exp Cell Res 40: $154-158$. 
Orlic D, Kajstura J, Chimenti S, Limana F, Jakoniuk I, Quaini F, Nadal-Ginard B, Bodine DM, Leri A \& Anversa P (2001) Mobilized bone marrow cells repair the infarcted heart, improving function and survival. Proc Nat. Acad Sci USA 98: 10344-10349.

Pesce M, Gross MK \& Scholer HR (1998) In line with our ancestors: Oct-4 and the mammalian germ. Bioessays 20: 722-732.

Petersen BE, Bowen WC, Patrene KD, Mars WM, Sullivan AK, Murase N, Boggs SS, Greenberger JS \& Goff JP (1999) Bone marrow as a potential source of hepatic oval cells. Science 284 : 1168-1170.

Pontecorvo G (1976) Production of indefinitly multiplying mammalian somatic cell hybrids by polyethylene glycol (PEG) treatment. Somatic Cell Genet 1: 397-400.

Poste G \& Reeve P (1971) Formation of hybrid cells and heterokaryons by fusion of enucleated and nucleated cells. Nature, New Biol 229: 123-125.

Poste G \& Reeve P (1972) Enucleation of mammalian cells by cytochalasin B. II. Formation of hybrid cells and heterokaryons by fusion of anucleate and enucleated cells. Exp Cell Res 73: 287-294.

Prescott DM, Meyerson D \& Wallace J (1972) Enucleation of mammalian cells with cytochalasin B. Exp Cell Res 71: 480-485.

Rao P \& Johnson RT (1970) Mammalian cell fusion: Studies on the regulation of DNA synthesis and mitosis. Nature 225: 159-164.

Resnitzky DM, Gossen M, Bujard H \& Reed SI (1994) Acceleration of the G1/S phase transition by expression of cyclins D1 and E with an inducible system. Mol Cell Biol 14: 1669-1679.

Ringertz NR \& Savage RE (1976) Cell Hybrids. Academic Press, New York.

Ruddle FH, Chapman VM, Ricciuti F, Murnane M, Klebe R \& Meera Khan P (1971) Linkage relationships of seventeen human gene loci as determined by man-mouse somatic cell hybrids. Nature, New Biol 232: 69-73.

Ruddle FH \& Kucherlapati RS (1974) Hybrid cells and human genes. Sci Am 231: 36-44.

Russo S, Tomatis D, Collo G, Tarone G \& Tato F (1998) Myogenic conversion of NIH3T3 cells by exogenous MyoD family members: Dissociation of terminal differentiation from myotube formation. J Cell Sci 111: 691-700.

Sata M, Saiura A, Kunisato A, Tojo A, Okada S, Tokuhisa T, Hirai H, Makuuchi M, Hirata Y \& Nagai R (2002) Hematopoietic stem cells differentiate into vascular cells that participate in the pathogenesis of atherosclerosis. Nature Med 8: 403-409.

Schneider JA \& Weiss MC (1971) Expression of differentiated functions in hepatoma cell hybrids. I. Tyrosine aminotransferase in hepatoma-fibroblast hybrids. Proc Natl Acad Sci USA 68: 127-131.

Shimizu K, Sugiyama S, Aikawa M, Fukumoto Y, Rabkin E, Libby P \& Mitchell RN (2001) Host bone-marrow cells are a source of donor intimal smooth-muscle-like cells in murine aortic transplant arteriopathy. Nature Med 7: 738-741.

Spear BT \& Tilghman SM (1990) Role of alpha-fetoprotein regulatory elements in transcriptional activation in transient heterokaryons. Mol Cell Biol 10: 5047-5054.

Surani MA (2001) Reprogramming of genome function through epigenetic inheritance. Nature 414: 122-128.
Szybalski W, Szbalski EH \& Ragni G (1962) Genetic studies with human cell lines. Natl Cancer Inst Monograph 7: 75-89.

Tada M, Tada T, Lefebvre L, Barton SC \& Surani MA (1997) Embryonic germ cells induce epigenetic reprogramming of somatic nucleus in hybrid cells. EMBO J 16: 6510-6520.

Tada M, Takahama Y, Abe K, Nakatsuji N \& Tada T (2001) Nuclear reprogramming of somatic cells by in vitro hybridization with ES cells. Curr Bio 11: 1553-1558.

Takagi N, Yoshida MA, Sugawara O \& Sasaki M (1983) Reversal of X-inactivation in female mouse somatic cells hybridized with murine teratocarcinoma cells in vitro. Cell 34: 1053-1062.

Taylor MV (2002) Muscle differentiation: How two cells become one. Curr Biol 12: R224-R228.

Terada N, Hamazaki T, Oka M, Hoki M, Mastalerz DM, Nakano Y, Meyer EM, Morel L, Petersen BE \& Scott EW (2002) Bone marrow cells adopt the phenotype of other cells by spontaneous fusion. Nature 416: 542-545.

Theise ND, Nimmakayalu M, Gardner R, Illei PB, Morgan G, Teperman L, Henegariu O \& Krause DS (2000) Liver from bone marrow in human. Hepatology 32: 11-16.

Tsai YL, Kittappa R \& McKay RDG (2002) Plasticity, niches, and the use of stem cells (Meeting review). Develop Cell 2: 707-712.

Veomett G, Prescott DM, Shay J \& Porter KR (1974) Reconstruction of mammalian cells from nuclear and cytoplasmic components separated by treatment with cytochalasin B. Proc Natl Acad Sci USA 71: 1999-2002.

Vignery A (2000) Osteoclasts and giant cells: Macrophagemacrophage fusion mechanisms. Intnatl J Exptl Path 81: 291304.

Weiss MC \& Green H (1967) Human-mouse hybrid cell lines containing partial compements of human chromosomes and functioning human genes. Proc Natl Acad Sci USA 58: 1104-1111.

Weissman IL, Anderson DJ \& Gage F (2001) Stem and progenitor cells: Origins, phenotypes, lineage commitments, and transdifferentiation. Annu Rev Cell Dev Biol 17: 387-403.

White JM \& Rose MD (2001) Yeast mating: Getting close to membrane merger. Curr Biol 11: R16-R20.

Wilmut I, Beaujean N, de Sousa PA, Dinnyes A, King TJ, Paterson LA, Wells DN \& Young LE (2002) Somatic cll nuclear transfer. Nature 419: 583-586.

Wimmel A, Lucibello FC, Sewing A, Adolf S \& Muller R (1994) Inducible acceleration of G1 progression through tetercyclineregulated expression of human cyclin E. Oncogene 9: 995-997.

Wright WE \& Hayflick L (1972) Formation of anucleate and multinucleate cells in normal and SV40 transformed WI-38 by cytochalasin B. Exp Cell Res 74: 187-194.

Wu KJ, Samuelson LC, Howard G, Meisler MH \& Darlington GJ (1991) Transactivation of pancreas-specific gene sequences in somatic cell hybrids. Mol Cell Biol 11: 4423-4430.

Yeom YI, Fuhrmann G, Ovitt CE, Brehm A, Ohbo K, Gross M, Hubner K \& Scholer HR (1996) Germline regulatory element of Oct-4 specific for the totipotent cycle of embryonal cells. Develop 122: 881-894.

Ying QL, Nichols J, Evans EP \& Smith AG (2002) Changing potency by spontaneous fusion. Nature 416: 545-548.

Zepp HD, Conover JH, Hirschhorn K \& Hodes HL (1971) Humanmosquito somatic cell hybrids induced by ultraviolet-inactivated Sendai virus. Nature, New Biol 229: 119-121. 